white barium salt obtained from the supernatant has an activity of 240 units per mgm. It completely inhibits Staphylococcus in a dilution of 1 in 5,000,000, partially in a dilution of 1 in 16,000,000.

The behaviour of sulphanilamide, $p$-aminobenzoic acid and chemically related compounds, aniline and sodium benzenesulphonate, at the surface of Bact. coli has been studied by Dr. F. R. Bradbury and D. O. Jordan by electrokinetic methods. The shapes of the curves relating variation of mobility with time of contact for sulphanilamide and $p$-aminobenzoic acid are quite different from those of the curves for aniline and sodium benzenesulphonate. The curves for sulphanilamide and $p$-aminobenzoic acid are similar, suggesting that the two compounds behave in a like manner at the bacterial surface.

Prof. A. St. G. Huggett said that dyes such as chlorazol sky blue F $P S$ (Chicago blue) and chlorazol fast pink $B K S$ are excellent anticoagulants. Structurally, they resemble afridol violet, from which Bayer 205 is derived; they have a trypanocidal action while Bayer 205 has an anticoagulant action. The dyes act at two points in the clotting mechanism as antikinase and antithrombin. Their anti-enzyme action with blood clotting may have an analogy to their mechanism as trypanocidal agents.

\title{
CO-ORDINATION OF SCIENTIFIC AND TECHNICAL WORK
}

\begin{abstract}
A a conference organized by the Association of A Scientific Workers and held at Birmingham on December 6, the need for greater co-ordination and collaboration in all fields of applied science was urged. The essential part which the scientific worker has to play in the modern community was emphasized by Mr. D. P. Riley, who opened a discussion on "The Responsibilities of the Scientist to the Community". Not only most of the greatest industries but even agriculture are dependent upon his work if they are to develop rapidly enough to satisfy the needs of the whole community, and in time of war it is even more important that this should be recognized, particularly in view of the five years' start which our enemies have over us in the application of science to war problems. As an interesting example of the need for the proper understanding of the scientific facts underlying certain decisions by those entrusted with executive power, Mŕ. Riley took the case of the encouragement of the consumption of wholemeal bread on account of its vitamin B content. The fact that this bread also contains an appreciable amount of phytic acid, the calcium salt of which is insoluble, and the consequent danger of avoiding vitamin B deficiency only at the expense of incurring calcium deficiency, has apparently not yet been given attention in public policy. Not only are many scientific workers still not occupied to their full capacity, but they are even in some cases urged to give their attention to the development of post-war plans, as well illustrated by an advertisement in a well-known daily paper describing a sewing-machine made largely of plasties and saying that now is the time to plan its post-war production.
\end{abstract}

The Association of Scientific Workers, which is working to secure the fullest application of science in the service of the community and a responsible status for men of science, is trying to meet the need for organization without which the individual man of science can do little in his attempt to ensure that his work is used for the war effort. In particular, the Association wishes for any evidence of definite misapplication or inefficiency in the use of scientific man-power, since it has been requested by the Ministry of Supply to prepare a report on this subject.

The immediate problems of producing and maintaining equipment for our armed forces was dealt with by Mr. Swann in his address on "The Role of the Scientist in the National Effort". He produced figures to demonstrate the superiority of Germany and the occupied countries over ourselves and the U.S.S.R., including also the help given by the United States, leaving no ground for optimism. He men. tioned the dissipation of effort in competition between private firms, the operation of the 'cost-plus' contract, inadequate pooling of information and the determined grip of firms on their trade secrets as some of the many factors combining to hold up production, and criticized the feeling of complacency fostered by Russia's successes and America's promises of support. $\mathrm{He}$ urged the formation of production committees, where these do not already exist, on which technical staff should play an active part, and the need to provide the Ministry of Supply with all relevant facts as to means to eradicate inefficiencies.

Mr. J. A. Henley pointed out how, as the industrial scientist has passed from the position of being an independent consultant or even his own manager to that of one wage-earner among many in a large firm, it has become necessary for him to co-operate with his fellows in a professional organization which could look after his interests and his status. This need has become peculiarly great since the outbreak of war ; hence it is not surprising that the Association of Scientific Workers has grown very much faster since its registration as a trade union than formerly.

After discussion, the following resolutions were passed :

"The Birmingham Conference of Scientific and Technical Workers reciprocates the expressed desire of the scientists of the U.S.S.R. for the fullest possible co-operation in the fight against Fascism, and pledges its maximum efforts to this end.

"This Conference, realising that maximum efficiency in the war effort will be achieved only as a result of fullest possible co-operation between technical staffs, work-people, and those in control of production, supports all activities leading to this end, in particular the setting up of production committees.

"This Conference calls for complete pooling of technical information between manufacturing companies with similar problems.

"This Conference stresses that the present anomalies in conditions of working and remuneration must lead to grievances that seriously hamper the war effort." 